JFBM

11,2

\section{8}

Received 28 April 2019 Revised 28 October 2019 Accepted 21 December 2019

\title{
Corporate social responsibility in Austrian family firms: socioemotional wealth and stewardship insights from a qualitative approach
}

\author{
Michael Kuttner
}

Institute for Management Control and Consulting, Johannes Kepler University Linz, Linz, Austria and

Department of Management Accounting and Finance Business School, Salzburg University of Applied Sciences, Urstein Süd, Puch

Birgit Feldbauer-Durstmüller

Institute for Management Control and Consulting, Johannes Kepler University Linz, Linz, Austria, and

Christine Mitter

Department of Management Accounting and Finance, Business School, University of Applied Sciences, Salzburg, Austria

\begin{abstract}
Purpose - This paper provides a comprehensive view about corporate social responsibility (CSR) in Austrian family firms. In detail, the conceptual understanding, motives for, institutionalisation, planning and the outcomes of CSR are investigated. The authors refer to socioemotional wealth and stewardship aspects as explanation approaches for CSR in family firms.

Design/methodology/approach - This study offers new insights into CSR in Austrian family firms based on qualitative data from 30 companies.

Findings - The findings demonstrate that despite numerous social, environmental and economic activities, referral to CSR is just in the beginning, indicating a lack of dissemination of the concept of CSR. The main motives for CSR engagement are image and reputation concerns, a strengthened regional embeddedness and employee-related improvements. Social CSR activities concerning employees and the close company surroundings dominate, whilst environmental CSR measures are often determined by the need for fulfilling the requirements of eco-certifications.

Originality/value - This paper contributes to the existing CSR literature by offering deeper insights into CSR in Austrian family firms (e.g. motives and outcomes of CSR), which are discussed under socioemotional wealth and stewardship aspects. Moreover, a broad range of implications for future research and corporate practice (e.g. family firms, owning family, policy) are discussed.
\end{abstract}

Keywords Austria, Corporate social responsibility (CSR), Family business, Family firms, Socioemotional wealth, Stewardship theory

Paper type Research paper

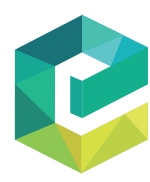

Journal of Family Business Management Vol. 11 No. 2, 2021 pp. 238-253 Emerald Publishing Limited 2043-6238

DOI 10.1108/JFBM-04-2019-0028

\section{Introduction}

Corporate social responsibility (CSR) in family firms has gained increasing attention within the last decade (e.g. Muttakin et al., 2015; Sundarasen et al., 2016) and addresses different focal

\footnotetext{
(C) Authors. Licensed re-use rights only

We thank our interview partners for their willingness to participate in our study. Our thanks also go to the Master's students of the Institute for Management Control and Consulting who were involved in collecting the data.
} 
points, such as CSR performance (McGuire et al., 2012; Yu et al., 2015), CSR reporting (Campopiano and De Massis, 2015; Cuadrado-Ballesteros et al., 2015), CSR engagement (Cruz et al., 2014; Laguir et al., 2016) and ownership effects on CSR (Block and Wagner, 2014; Sundarasen et al., 2016). However, findings within the research field of CSR in family firms exhibit a great heterogeneity and remain unstructured (Van Gils et al., 2014; Kuttner and Feldbauer-Durstmüller, 2018), for instance, authors have found different results of the impacts of family influence on CSR: positive (e.g. Bingham et al., 2011; Uhlaner et al., 2012), negative (e.g. Huang et al., 2014) and no impacts on CSR (e.g. Wagner, 2010; McGuire et al., 2012). Thus, different scholars have called for further CSR research within family firms under different focal points (e.g. Berrone et al., 2010; Van Gils et al., 2014; Preslmayer et al., 2018).

The great scientific interest in CSR in family firms leads back to family firms' worldwide domination of the corporate landscape and their relevance as employers (IFERA, 2003; Hiebl, 2014). In contrast to non-family firms, family firms possess specific characteristics influencing CSR (e.g. strong emotional ties between the owning family and the family firm, strong involvement in the direct company surroundings, transgenerational focus, long-term orientation). Family firms increasingly use CSR to fulfil the emotional needs of the family and the firm (e.g. to maintain and increase image and reputation) (Dyer and Whetten, 2006; Berrone et al., 2010; Zellweger et al., 2013). Nevertheless, there is no comprehensive view about CSR in family firms, offering detailed findings about conceptual understanding, motives for CSR, CSR measures, institutionalisation and planning as well as outcomes of CSR activities. To fill this research gap, we examine the aforementioned unique family firm characteristics under socioemotional wealth and stewardship aspects by investigating 30 Austrian family firms. In detail we aim to answer the following research questions:

\section{How is the conceptual understanding of CSR?}

Which motives determine CSR measures and which CSR measures are carried out?

How is CSR institutionalised and planned and to which outcomes do CSR activities lead?

Our article proceeds as follows. After the introductory section, the underlying theoretical background is explained and discussed, followed by the methodology and the presentation of the findings. We conclude with a discussion, based on socioemotional wealth and stewardship theory, and derive implications for further research and corporate practice, as well as the limitations of this study.

\section{Theoretical background}

\subsection{Corporate social responsibility in Austria}

Following Carroll (1999), the modern era of CSR dates back to Bowen (1953), who used the term CSR for the first time and pointed out that CSR requires an orientation towards the expectations, goals and values of a society. Since then, the concept of CSR has evolved and meanwhile, there are numerous existing definitions within academics and corporate practice (Dahlsrud, 2008; Rahman, 2011), comprising also aspects derived from CSR such as corporate social performance (Wartick and Cochran, 1985; Wood, 1991) or similar or closely related issues such as sustainability (Glavič and Lukman, 2007; Morelli, 2011) or business ethics (Epstein, 1987). Following Jones (2009), essential contributions to CSR were made amongst other authors by Wood (1991, p. 695), who argues that "the basic idea of CSR is that business and society are interwoven rather than distinct entities; therefore, society has certain expectations for appropriate business behaviour and outcomes", and Porter and Kramer (2006), who discuss a possible strategic advantage of CSR.

This paper deals with CSR in Austrian family firms, where CSR is strongly influenced by the European Union and its CSR understanding (Commission of the European Communities, 2001). The public CSR discussion in Austria began recently, in 2002, due to the increasing CSR debates within the European Union (Strigl,

\section{CSR in \\ Austrian family firms}

239 
JFBM

11,2

2005; Mark-Ungericht and Weiskopf, 2007). Nevertheless, social and environmental measures always had a great relevance within Austria, for example, a high degree of social protection, a high level of organic and sustainable farming, high environmental protection requirements, the abandonment of nuclear power plants and a dual apprenticeship training system, which combines school education and on-the-job training (Strigl, 2005).

\section{0}

\subsection{Family firms}

Different authors acknowledge the worldwide presence and relevance of family firms (e.g. Gedajlovic et al., 2012; Sharma et al., 2012), which is also true for Austria. Depending on the chosen definition, 51-88\% of all companies in Austria are family firms (including small craft businesses as well as global corporations). Even if the narrowest definition is applied, Austrian family firms employ $65 \%$ of the Austrian workforce and generate $57 \%$ of the Austrian business revenue (WKO, 2018), illustrating the dominance of this firm type in Austria. Although a commonly accepted definition of the term family firm is lacking (e.g. Sharma et al., 2012; Steiger et al., 2015), scholars like Allouche et al. (2008) and Amann et al. (2012) argue that most definitions include three dimensions: (1) ownership (a significant part of the firm's capital must be held by one or several families); (2) management (family members must retain significant control over the firm, in terms of capital distribution and voting rights among non-family shareholders); and (3) control (family members must hold top management positions). For the purpose of our qualitative study, we follow this dimensional view of family firms.

\subsection{Socioemotional wealth}

Socioemotional wealth (e.g. Berrone et al., 2012; Labelle et al., 2018) has gained. In their seminal paper, Gómez-Mejía et al. (2007, p. 106) refer socioemotional wealth to "non-financial aspects of the firm that meet the family's affective needs such as identity, the ability to exercise family influence, and the perpetuation of the family dynasty." Put differently, decisions within family firms are driven by the dominant family principal(s) to preserve nonfinancial aspects (called "affective endowments"), such as maintaining image and reputation (Gómez-Mejía et al., 2007). Gómez-Mejía et al. (2011) argue that reasons for the dominance of non-economic factors in decision-making within family firms are mainly attributable to (1) the importance of emotions between the owning family and its business, (2) the relevance of values and their preservation (e.g. during succession) and (3) altruistic behaviour of the members of the owning family to contribute to the common good of the family firm. Hence, to preserve socioemotional wealth, decisions by the owning family or the family principal(s) are not always driven by a certain economic logic, and even risks for the family firms are accepted for socioemotional wealth preservation (Berrone et al., 2012). Following Berrone et al. (2012), socioemotional wealth involves the following five dimensions: The first dimension, family control and influence, is connected with the family members' control over the family firm's strategic decisions (Chua et al., 1999). Control can be exercised in different ways family members or a dominant family coalition can be part of the management team or supervisory board to exercise control, or control can be exerted in an indirect way (e.g. appointing top management). However, to preserve socioemotional wealth, continued control of the family firm through family members is required (Berrone et al., 2012). The second dimension of socioemotional wealth is the identification of family members with the firm. Due to the close connection between the owning family and the family firm, a unique identity between family members and the family firm is created (Dyer and Whetten, 2006; Berrone et al., 2010). Hence, image and reputation concerns are integral parts of the preservation of non-financial aspects (Berrone et al., 2012).

Binding social ties, the third dimension of socioemotional wealth (Berrone et al., 2012) refers to tight and trusting relationships between family firms and different internal (e.g. 
non-family employees) and external stakeholders (e.g. customers and suppliers). Non-family employees often share the values of the family firm and its owning family (Miller and Le Breton-Miller, 2005b). Furthermore, family firms often have long-lasting relationships with customers and suppliers, who are often considered as members of the family (Uhlaner, 2006). The fourth dimension, emotional attachment of family members, addresses the role of emotions within family firms (Berrone $e$ t al., 2012). Emotions and affections show a greater complexity within family firms than non-family firms (Fletcher, 2000), and the connection of emotions and business within family firms is one of the key distinguishing features between family firms and non-family firms (Tagiuri and Davis, 1996). Consequently, emotions and sentiments impact decision-making and are often regarded as important as economic considerations (Berrone et al., 2012). Finally, the fifth dimension, renewal of family bonds to the firm through dynastic succession, refers to the longer time horizon of family firms compared with non-family firms, due to the intention to maintain the family firm for future generations (Berrone et al., 2010). The longer time horizon influences, for instance, decision-making (Berrone et al., 2010) or the planning process (Sirmon and Hitt, 2003).

\subsection{Stewardship theory}

Stewardship theory (Davis et al., 1997) is an often-used theoretical perspective for analysing CSR in family firms (e.g. Marquès et al., 2014; Laguir et al., 2016) and provides explanations for non-economic behaviour (Donaldson and Davis, 1991). For example, managers often act in an altruistic way, which could lead to benefits for the organisation and the stakeholders (Davis et al., 1997). So-called stewards are intrinsically motivated and "act for the collective good of their firms" (Miller and Le Breton-Miller, 2006, p. 74), even if this comes with personal disadvantages (Davis et al., 2000).

According to Miller et al. (2008), stewardship theory has three forms of expression within family firms: (1) stewardship over continuity, (2) over employees and (3) over customers. Stewardship over continuity addresses the longevity of family firms as overall objective. Family firms even accept short-term losses to ensure long-term survival (Miller et al., 2008) and are characterised by a transgenerational focus, or in other words, there is a strong intention in family firms to hand the business over to future generations (Zellweger et al., 2012). Due to the strong emotional ties between the owning family and the family firm (Gómez-Mejía et al., 2007), family and business success are interdependently linked (e.g. career opportunities of family members, image and reputation issues) (Le Breton-Miller and Miller, 2009).

Stewardship over employees refers to strong commitment towards employees and the careful nurturing of the workforce in order to foster motivation and loyalty of employees (Miller et al., 2008). This can be achieved through different measures, for instance, a greater range of responsibilities, staff training and the transfer of values and norms from the owning family to employees (Miller and Le Breton-Miller, 2005a, Arregle et al., 2012). Consequently, family firms' employees often share values and norms with the owning family, resulting in closer and more personal relationships, loyalty to the family firm and longer tenures (Miller and Le Breton-Miller, 2005a; Le Breton-Miller and Miller, 2006).

The third form of expression, stewardship over customers, focuses on customers and especially on increasing their loyalty to the family firm by building up a relationship beyond business (Miller et al., 2008). By fostering the partnership between customers and the family firm, a mutual understanding for each other and a high level of trust are created (Le Breton-Miller and Miller, 2009). This approach is extended to other stakeholders such as suppliers or strategic partners with whom family firms also aim to develop close and trusting relationships (Sirmon and Hitt, 2003; Arregle et al., 2012).

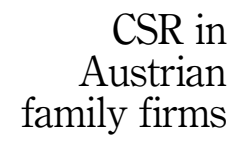


JFBM

11,2
2.5 Corporate social responsibility in family firms

Socioemotional wealth has offered new insights into CSR in family firms (e.g. Berrone et al., 2010; McGuire et al., 2012; Cruz et al., 2014; Marquès et al., 2014) and "plays a key role in how family companies conceptualize and practice CSR" (Zientara, 2017, p. 186). Similarly, stewardship theory offers manifold explanations for the CSR engagement of family firms. For instance, stewardship over continuity, the identification of the family members with the firm, emotional attachment and the wish for dynastic succession (dimensions of socioemotional wealth) result in a high significance of image and reputation in family firms (Sageder et al., 2018). Hence, CSR engagement is linked to the fulfilment of emotional needs of the owning family and aims at maintaining and establishing image and reputation (Dyer and Whetten, 2006; Zellweger et al., 2013).

As a result of stewardship over employees and a strong regional embeddedness (as manifestation of binding social ties), family firms feel obliged to care for their workforce and local community. Marquès et al. (2014), for example, found evidence for the preference of social CSR activities within family firms particularly if employees and the immediate community are addressed.

Binding social ties and close relationships towards customers and other stakeholders may also explain the importance of image and reputation in family firms. Given their desire to form trusting partnerships with stakeholders, family firms wish to serve customers with high-quality products and invest considerably in these partnerships. This also applies in the context of CSR, where family firms were found to pursue quality and innovation strategies (Kammerlander and Ganter, 2015), to provide excellent service (Levenburg, 2006; Carrigan and Buckley, 2008; Orth and Green, 2009) and to minimise negative incidents related to their products (Block and Wagner, 2014; Kashmiri and Mahajan, 2014a).

\section{Methodology}

In line with previous studies on CSR in family firms (e.g. Laguir et al., 2016), we chose an explorative, qualitative research design. Qualitative research offers the opportunity to focus on complex phenomena within their contexts and is used to provide critical and reflexive perspectives (Eriksson and Kovalainen, 2015). Specifically, qualitative research is suitable for in-depth investigations (Yin, 2013).

Data was collected through semi-structured, problem-focused interviews and analysed by using the general inductive approach (Thomas, 2006). In total, data stems from 30 medium- and large-sized Austrian family firms (size categorisation of the European Commission, 2003)[1]. Small family firms were not considered because CSR is often univocally labelled and often informally operated (Morsing and Perrini, 2009; Soundararajan et al., 2017). Further eligibility requirements include firms that actively engage in CSR and where an employee could be identified that is responsible for CSR activities and has decision-making power within the family firm (e.g. managing director, chief financial officer, marketing manager). Similar to Laguir et al. (2016), we developed a theory-based interview guide to define main themes for the interviews:

(1) Family firm and interviewee characteristics

(2) Understanding of CSR

(3) Motives for CSR and CSR measures

(4) Institutionalisation and planning of CSR

(5) Outcomes of CSR activities (self-perception) 
Family firms were selected by an online search to ensure their social, environmental and economic engagement. After the case family firms were chosen, potential interview partners were contacted via telephone, and after the commitment to an interview was made, a brief description of the aims and design of the qualitative study, as well as the theory-based interview guide, was sent via email to the interviewees. In sum 30 persons responsible for CSR out of 30 family firms agreed to participate in our study.

All participants were interviewed at their respective company locations between March and June 2017. A pre-test of the interview guide was conducted during the first interview. Afterwards, interviews were promptly transcribed, resulting in more than 500 text pages. If necessary, interview partners were contacted by telephone for further questions. Moreover, participants were given the opportunity to check and, if necessary, to adjust the transcription. To conduct our study in English, relevant text passages were translated from German to English by retaining the general meaning.

Following the general inductive approach set out by Thomas (2006), we evaluated the data generated by the semi-structured, problem-oriented interviews using the software MAXQDA. Through repeated reading and interpretation of the data, we determined the analysers, paraphrased the content-bearing passages, determined the level of abstraction and generalisation, gradually reduced data and created the categories (e.g. conceptual understanding, CSR measures) presented in the following section. Furthermore, the developed categories were reviewed with findings from the literature, whereby new insights into CSR in Austrian family firms were discovered.

\section{Results}

Our results demonstrate that within Austrian family firms (FFs), social, environmental and economic measures are rarely fulfilled under the concept of CSR due to the lack of the widespread use of the term CSR. Only in recent years family firms have consciously begun to refer to CSR when acting socially, environmentally and economically responsible. Nevertheless, most family firms act responsibly albeit not under the term CSR, as the following statements confirm: "We engaged in CSR long before the concept came to people's minds. Social engagement has been a staple part of the company for many years. Of course, the engagement has increased with business growth and changing social conditions. Nevertheless, CSR has always been there (Interviewee FF 7)." "The company has been working on CSR for a while now, as the word is now known. (. . .) in my opinion, the term CSR is a trendy word that has been around for a long time in family firms (Interviewee FF 21)." Since the upcoming CSR discussion, social, environmental and economic activities were repacked under the term CSR but are basically not new within family firms, as the interviewee from FF 7 explains: "Sustainability has always been practiced in the company, but not under the term CSR."

Within the sampled family firms, a broad range of motives for CSR engagement exists. Frequent statements are image and reputation issues, as the interviewee from FF 29 exemplifies: "Motives for CSR mainly lie in the improvement of our reputation, to stand out from our competitors." Another frequently mentioned motive for CSR is increased regional embeddedness (e.g. FFs 1, 19, 24 and 27). Interviewees argue that the family firm has to assume responsibility for the region, especially as there are only few leading companies (FF 19), and mention the improvement of the image and perception of the family firm within the close company surroundings (FF 10). Further motives for CSR include employee-related answers (e.g. FFs 6, 14, 18 and 19), as the following statement of interviewee from FF 8 illustrates: "We defined several strategic goals for our CSR activity. One main goal was to become the best employer in the region."

Unsurprisingly, a wide range of different CSR activities were carried out within the investigated family firms, addressing social, environmental and economic aspects of CSR. Social

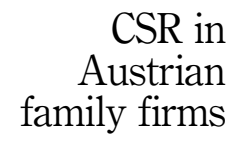


JFBM

11,2

CSR activities are the largest group within our study, and all measures concerning employees are particularly important for Austrian family firms, including flexible working hours (e.g. FFs 6, 8, 13 and 20), company-owned childcare (e.g. FFs 14, 16 and 18), emergency funds for employees (e.g. FFs 19 and 20), regular sporting events (e.g. FFs 1, 6 and 11), health care and job security (e.g. FFs 11 and 17), employee development (e.g. FFs 3, 21 and 26) and so on. The following statement emphasises the importance of CSR measures for employees: "Most important are measures concerning employees" (Interviewee FF 14).

Another focus within the case firms was directed at social CSR measures addressing the regional involvement: "Of course, we mainly support CSR activities in our close regional surroundings, at this and at our other locations" (Interviewee FF 4). However, family firms within the sample engage in a wide range of social CSR measures, even abroad, which often depends on the intentions of family members, as the interviewee from FF 22 explains: "We have founded a children's home in Africa. That is mostly due to the intention of our owner. He has been there several times, including with his family. Since then, we support the children living in the children's home in Africa."

Although social activities are of the greatest relevance to family firms, and the influence of the owner is often noticeable, family firms also engage in environmental and economic measures. We found a wide range of environmental measures, including, for instance, energy-saving measures (e.g. FFs 13, 18 and 26), minimisation of traffic and transport routes (e.g. FFs 1 and 9), sustainable use of resources (e.g. FFs 12 and 27), alternative packaging (e.g. FF 12) and cooperative projects with agriculture (e.g. FF 1). In this context, environmental measures are often influenced by the necessity to fulfil the requirements of eco-certifications, as the interviewee from FF 16 explains: "We have several environmental and quality certifications. Furthermore, there are several annual goals, which must be achieved to get a re-certification." There are also economic CSR measures within the family firms, addressing almost solely customers and suppliers and which are of great relevance at the product level. For instance, the interviewee from FF 19 mentions that emphasis is placed on customers and supply chains - a criteria catalogue was created for sustainable cultivation of delivered products. Moreover, the interviewee from FF 15 argues that CSR is built on longevity and responsibility; more specifically, it is built to be in harmony with society, the environment and in particular with customers and suppliers.

Concerning institutionalisation, the findings of the cases demonstrate that CSR is rarely institutionalised. In almost two-thirds of the cases, management (e.g. managing director, chief executive officer, chief financial officer) is responsible for CSR; in other words, CSR is assigned to the top management or extended management team. In seven cases, CSR is principally assigned to the marketing or public relations departments (e.g. FFs 6 and 22) and in one case to the quality management (FF 26). CSR-related positions within the family firms were only found in two cases: CSR representative (FF 16) and head of sustainable development ( $\mathrm{FF} 29$ ). The following statements exemplify the lack of institutionalisation within the case firms: "A separate department does not exist because (...) our company is simply too small" (Interviewee FF 22). "We have no employee or department in charge of CSR. (...) Every employee in the company bears these values" (Interviewee FF 6). Institutionalisation approaches are only found in three cases (FFs 16, 17 and 29). For instance, in FF 17, CSR is part of the marketing department and the implementation of CSR measures is decentralised, as the interviewee from FF 17 explains: "CSR is in my department; however, each employee is responsible for CSR." The ultimate decision-making power, however, is borne by top management (Interviewee FF 29). Similar results are given for the planning and budgeting of CSR measures. Hence, planning in general appears to have minor relevance within Austrian family firms and budgets for certain CSR projects are often determined on an ad hoc basis, as the following statement exemplifies: "Financial measures are weighed from project to project" (Interviewee FF 7). Furthermore, the dedicated amount differs according to 
the intention of the family, as the statement of the interviewee from FF 10 illustrates: "Do we have a budget for CSR? Such a procedure is rare in family firms. It strongly depends on the owning family and their attitude."

In general, according to the interviewees, CSR activities in Austrian family firms lead to positive outcomes. For instance, an increased employee motivation (e.g. FFs 8, 12 and 14), a lower number of sicknesses (e.g. FFs 1, 11 and 13), reduced problems in employee recruitment (e.g. FFs 8 and 24), stronger regional involvement (e.g. FF 28) and positive environmental effects (e.g. FFs 12, 16, and 27).

\section{Discussion}

Socially, environmentally and economically responsible activities have always been a part of Austrian family firms, although these activities were in the past rarely associated with the term CSR. The long tradition of these measures may be explained with the nature of family firms, where non-financial aspects (Gómez-Mejía et al., 2007) and the transgenerational focus or, in other words, the long-term orientation of family firms (renewal of family bonds and stewardship over continuity) have always been of particular relevance. While our findings demonstrate that within Austrian family firms the term CSR is not completely unknown, their CSR activities are hardly derived from a thorough conceptual understanding of CSR.

Concerning CSR motives within Austrian family firms, most attention is paid to image and reputation issues, regional embeddedness and employee-related improvements. Image and reputation issues as motives for CSR are mentioned by a vast number of scholars (e.g. Dyer and Whetten, 2006; Berrone et al., 2010; Campopiano and De Massis, 2015) and are the result of the close link between the owning family and the family firm as well as the desire for continuity and transgenerational survival. A further motive addressing socioemotional wealth is regional embeddedness, which is mostly due to deep roots of the family firm and the owning family in the region (as manifestation of binding social ties). Another explanation could be provided by stewardship over customers, especially if the family firm and the customers are located in the same region and customers are considered as partners due to long-lasting relationships and loyalty. The large number of employee-related CSR motives could be another indicator of the strong social ties among the owning family, the family firm and its employees (including but not restricted to family members; Miller et al., 2009). Besides socioemotional wealth (in the form of binding social ties), stewardship over employees may explain the strong focus of employee-related CSR activities in order to increase motivation and loyalty and to tie qualified employees to the family firm in the long term.

Moreover, our study demonstrates that in Austrian family firms, social CSR measures concerning employees and the close surroundings of the family firms are predominant forms of CSR engagement. The importance of employee-related CSR measures in our sample firms may result from the high relevance of employee retention in Austria because of the lack of skilled workers, especially within rural regions, as well as the high costs of sick leave and employee fluctuation. Whilst other CSR measures (e.g. environmental and economic measures) exist, they are of minor importance in comparison.

Several authors mention the dominance of social CSR activities in family firms (e.g. Dyer and Whetten, 2006; Laguir et al., 2016), which could be due to the close connection of the image and reputation of the owning family and the family firm (Dyer and Whetten, 2006), as well as the strong embeddedness in the local community (Laguir et al., 2016), both indicating the importance of non-financial aspects covered by socioemotional wealth. Close emotional ties as one dimension of socioemotional wealth and stewardship over employees may explain the strong focus on employees in CSR activities who are often regarded as part of the family network because of long tenures, shared beliefs and values. Both family influence and regional involvement are often relevant criteria for the choice of CSR measures. The owning

\section{CSR in \\ Austrian family firms}


JFBM

11,2

family often has the last decision-making power. Whereas the family influence may be explained by the desired continuation of family control and influence, the regional embeddedness may refer to social ties between the owning family and the place where they work and live (Berrone et al., 2012).

Different previous studies found evidence that regional involvement is influencing CSR (e.g. Wagner, 2010; Sharma and Sharma, 2011; Marquès et al., 2014; Campopiano and De Massis, 2015). For instance, following Uhlaner et al. (2012), regional involvement influences the extent of environmental CSR activities. Environmental measures in Austrian family firms, however, are often determined to meet the requirements of eco-certifications. Given their missing or inadequate voluntary intention, classification of these activities as CSR measures appears questionable.

Extraordinary CSR measures (e.g. foundation of a children's home in Africa by FF 29), especially if there is no communication of such measures, can hardly result in an increased image and reputation and indicate a steward intention amongst members of the owning family. Such activities could also stem from emotions (e.g. compassion or concern) of the owning family and are thus a manifestation of the emotional attachment dimension. Decisions within family firms are affected by the emotions of the owning family (Berrone et al., 2012) and are not exclusively financially oriented (Gómez-Mejía et al., 2007).

Reasons for economic CSR measures addressing customers and suppliers aim at strengthening the relationship to foster trust and loyalty in the sense of stewardship over customers. In the case that CSR activities are built on longevity, socioemotional wealth (renewal of family bonds) and stewardship theory (stewardship over continuity) could deliver explanations.

Within Austrian family firms, CSR is rarely institutionalised. The few approaches for institutionalisation are marked by decentralisation. Moreover, planning and budgeting of CSR has minor importance in Austrian family firms. The financial means dedicated to CSR measures depend on the owning family's intention, emotions and sentiments. The low degree of institutionalisation in the case family firms may be the result of strong social ties and stewardship over employees. Given that family members as well as non-family employees share the same values and beliefs, the importance of non-financial goals, such as high-quality products as well as trusting and long-lasting relationships, is imprinted on the whole organisation. Consequently, every employee is familiar with the importance of non-financial goals, which - to a certain extent - are achieved through CSR activities. Thus, there is no need for a high level of institutionalisation.

In general, CSR in Austrian family firms leads to positive outcomes (e.g. stronger regional involvement), which were also found in previous studies such as increased employee motivation (e.g. Marquès et al., 2014; Schäfer and Goldschmidt, 2010), improved working conditions (e.g. Fernando and Almeida, 2012), higher employee attraction (Panwar et al., 2014), positive perception by society in general (e.g. Wiklund, 2006; Kashmiri and Mahajan, 2014b; Panwar et al., 2014) and positive environmental effects (e.g. Berrone et al., 2010; Huang et al., 2014). Furthermore, we acknowledge that CSR outcomes affect both the owning family and the family firm, due to their close relation, as mentioned by several authors (e.g. Dyer and Whetten, 2006; Le Breton-Miller and Miller, 2016). Finally, findings of our study are summarised in Figure 1.

\section{Conclusion}

This study is the first to address CSR in Austrian family firms. More specifically, we provide new and deeper insights into the (1) conceptual understanding of CSR, (2) motives for CSR and CSR measures, (3) institutionalisation and planning of CSR and (4) outcomes of CSR in Austrian family firms. Our findings of the 30 Austrian family firms share common ground with socioemotional wealth perspectives and stewardship theory. 


\begin{tabular}{|c|c|c|c|c|}
\hline Understanding of CSR & Motives for CSR & CSR measures & $\begin{array}{l}\text { Institutionalisation and } \\
\text { planning of CSR }\end{array}$ & Outcomes of CSR \\
\hline $\begin{array}{l}\text { - Socially, economically and } \\
\text { ecologically responsible } \\
\text { activities have always been } \\
\text { a part of Austrian family } \\
\text { firms, due to the nature of } \\
\text { family firms (strong focus } \\
\text { on non-financial aspects) } \\
\text { - These activities were rarely } \\
\text { associated with the term } \\
\text { CSR } \\
\text { - Lack of dissemination of the } \\
\text { concept of CSR within } \\
\text { family firms }\end{array}$ & $\begin{array}{l}\text { - Intention of the corporate } \\
\text { family } \\
\text { - Increased image and } \\
\text { reputation } \\
\text { - Increased regional } \\
\text { embeddedness } \\
\text { - Employee-related } \\
\text { improvements }\end{array}$ & $\begin{array}{l}\text { - Social CSR measures } \\
\text { concerning employees and } \\
\text { the close company } \\
\text { surroundings are } \\
\text { predominant } \\
\text { - Other CSR measures } \\
\text { (environmental and } \\
\text { ecological measures) exist, } \\
\text { but are of minor relevance } \\
\text { - Environmental CSR } \\
\text { measures are often } \\
\text { determined by eco- } \\
\text { certifications } \\
\text { - Extraordinary CSR } \\
\text { measures are in the } \\
\text { minority (e.g., foundation of } \\
\text { a children's home in Africa) }\end{array}$ & $\begin{array}{l}\text { - CSR within Austrian family } \\
\text { firms is rarely } \\
\text { institutionalized } \\
\text { - Institutionalization is } \\
\text { marked by decentralization } \\
\text { - Planning and budgeting of } \\
\text { CSR has minor importance } \\
\text { - The financial measures } \\
\text { often depend on the } \\
\text { intention of the owning } \\
\text { family }\end{array}$ & $\begin{array}{l}\text { - Stronger regional } \\
\text { involvement } \\
\text { - Positive environmental } \\
\text { effects } \\
\text { - Increased employee } \\
\text { motivation } \\
\text { - Reduced number of } \\
\text { sicknesses } \\
\text { - Reduced problems in } \\
\text { recruitment }\end{array}$ \\
\hline
\end{tabular}

\section{CSR in Austrian family firms}

247

Figure 1. Summary of findings

Moreover, several implications for future research remain. First of all, more research is required on CSR in family firms in general. For instance, consideration of different contingency factors (e.g. size, country) could provide new insights. Additionally, more research is needed on the conceptual understanding of CSR within family firms, as the CSR interpretation of family firms is crucial for future research (e.g. for the comparison of findings). Deeper insights into values and beliefs are required, which form the basis for the behaviour of the owning family and determine family influence. In general, the establishment of CSR in family firms offers more avenues for fruitful research, particularly the institutionalisation, planning and implementation of CSR activities. Referring to CSR outcomes in family firms, longitudinal and quantifiable effects are hardly addressed by academic research. Moreover, due to our focus on Austrian family firms, our findings could be compared with other countries and regions.

Furthermore, there are also several implications for corporate practice in family firms, especially for family firms and owning families. For instance, this study could be a good indicator for family firms that are not engaged in CSR or plan to implement CSR activities in the near future. Our study also points out the high relevance of a stakeholder-oriented and effective use of CSR measures and their communication. Especially communication is crucial for public perception and maintaining and increasing image and reputation. Our study indicates that social, environmental and economic activities have always been a part of Austrian family firms, long before CSR became trendy. Nevertheless, the link to CSR should be clearly highlighted and communicated to get rewarded for one's efforts. Additionally, the cases exhibit positive outcomes of CSR, and we therefore recommend to family firms an active CSR engagement. Especially employee-related CSR measures are becoming more and more important in Austria, where a high competition for qualified work staff exists. Particularly in recruiting, CSR can lead to an advantage of family firms that have a long tradition of CSR activities marked by a high level of decentralisation and integration of all employees. Moreover, this study could promote the understanding of the link between the owning family and the family firm in the context of CSR, especially for non-family employees as well as other interested people. Given the minor importance of planning and the rather random and ad hoc dedication of financial means to CSR activities, family firms and especially the owning family should be encouraged to act more structured and planned. This way, CSR measures may become more goal-oriented and their efficiency and desired outcome easier to track. Our study could also be interesting for legislators and politicians, who could 
JFBM

11,2

248

foster conceptual understanding of CSR within family firms by providing specific information about CSR, showing possible outcomes of CSR in family firms, organising events where entrepreneurs are informed about best practice CSR within model family firms or even promoting CSR consulting.

Nevertheless, there are certain limitations of our study. Firstly, due to the explorative nature of qualitative research, the small sample size and the specific country focus on Austria, we cannot generalise findings, although many results are supported by previous studies. Secondly, the interpretive and qualitative research orientation may have led to a subjective bias within the results. Thirdly, findings from the interviews reflect the subjective assessment of the individual interviewees, and thus the external perception could differ from our findings. Fourth, we conducted only one interview per family firm. More interviews may result in different findings and may be more beneficial for academic research. Fifth, firm representatives may try to present their family firm in a positive light, rather than admitting failures and negative outcomes of CSR. Sixth, our study solely considers family firms, whereas a comparison with other firm types (e.g. non-family firms or public organisations) could offer more detailed insights. Seventh, to confirm our findings, more research is required, with quantitative studies being of particular use in verifying our findings. Although our study was exploratory and possesses certain limitations (which may prove to be fruitful research avenues in the future), we deliver deep insights into CSR in family firms, especially for Austria. Moreover, we contribute to and foster a deeper understanding of CSR in family firms.

\section{Note}

1. According to the European Commission (2003), medium-sized enterprises employ between 50 and 249 persons and have an annual turnover exceeding EUR 10 million and not exceeding EUR 50 million and/or a balance sheet total exceeding EUR 10 million and not exceeding EUR 43 million. Large enterprises have 250 or more employees and an annual turnover exceeding EUR 50 million and/or an annual balance sheet exceeding EUR 43 million.

\section{References}

Allouche, J., Amann, B., Jaussaud, J. and Kurashina, T. (2008), "The impact of family control on the performance and financial characteristics of family versus nonfamily businesses in Japan: a matched-pair investigation”, Family Business Review, Vol. 21 No. 4, pp. $315-330$.

Amann, B., Jaussaud, J. and Martinez, I. (2012), "Corporate social responsibility in Japan: family and non-family business differences and determinants", Asian Business and Management, Vol. 11 No. 3, pp. 329-345.

Arregle, J.L., Naldi, L., Nordqvist, M. and Hitt, M.A. (2012), "Internationalization of family-controlled firms: a study of the effects of external involvement in governance", Entrepreneurship: Theory and Practice, Vol. 36 No. 6, pp. 1115-1143.

Berrone, P., Cruz, C. and Gómez-Mejía, L.R. (2012), "Socioemotional wealth in family firms: theoretical dimensions, assessment approaches, and agenda for future research", Family Business Review, Vol. 25 No. 3, pp. 258-279.

Berrone, P., Cruz, C., Gómez-Mejía, L.R. and Larraza-Kintana, M. (2010), "Socioemotional wealth and corporate responses to institutional pressures: do family-controlled firms pollute less?", Administrative Science Quarterly, Vol. 55 No. 1, pp. 82-113.

Bingham, J.B., Dyer, W.G., Smith, I. and Adams, G.L. (2011), "A stakeholder identity orientation approach to corporate social performance in family firms", Journal of Business Ethics, Vol. 99 No. 4 , pp. 565-585. 
Block, J.H. and Wagner, M. (2014), "The effect of family ownership on different dimensions of corporate social responsibility: evidence from large US firms", Business Strategy and the Environment, Vol. 23 No. 7, pp. 475-492.

Bowen, H.R. (1953), Social Responsibilities of the Businessman, University of Iowa Press, Iowa City, Iowa.

Campopiano, G. and De Massis, A. (2015), "Corporate social responsibility reporting: a content analysis in family and non-family firms", Journal of Business Ethics, Vol. 129 No. 3, pp. 511-534.

Carrigan, M. and Buckley, J. (2008), “What's so special about family business?' an exploratory study of UK and Irish consumer experiences of family businesses", International Journal of Consumer Studies, Vol. 32 No. 6, pp. 656-666.

Carroll, A.B. (1999), "Corporate social responsibility: evolution of a definitional construct", Business and Society, Vol. 38 No. 3, pp. 268-295.

Chua, J.H., Chrisman, J.J. and Sharma, P. (1999), "Defining the family business by behavior", Entrepreneurship: Theory and Practice, Vol. 23 No. 4, pp. 19-39.

Commission of the European Communities (2001), "Green Paper. Promoting a European framework for corporate social responsibility", available at: https:/eur-lex.europa.eu/legal-content/EN/ TXT/?uri=CELEX\%3A52001DC0366 (accessed 6 October 2019).

Cruz, C., Larraza-Kintana, M., Garcés-Galdeano, L. and Berrone, P. (2014), "Are family firms really more socially responsible?", Entrepreneurship: Theory and Practice, Vol. 38 No. 6, pp. 1295-1316.

Cuadrado-Ballesteros, B., Rodríguez-Ariza, L. and García-Sánchez, I.M. (2015), "The role of independent directors at family firms in relation to corporate social responsibility disclosures", International Business Review, Vol. 24 No. 5, pp. 890-901.

Dahlsrud, A. (2008), "How corporate social responsibility is defined: an analysis of 37 definitions", Corporate Social Responsibility and Environmental Management, Vol. 15 No. 1, pp. 1-13.

Davis, J.H., Schoorman, F.D. and Donaldson, L. (1997), "Toward a stewardship theory of management", Academy of Management Review, Vol. 22 No. 1, pp. 20-47.

Davis, J.H., Schoorman, F.D., Mayer, R.C. and Tan, H.H. (2000), “The trusted general manager and business unit performance: empirical evidence of a competitive advantage", Strategic Management Journal, Vol. 21 No. 5, pp. 563-576.

Donaldson, L. and Davis, J.H. (1991), "Stewardship theory or agency theory: CEO governance and shareholder returns", Australian Journal of Management, Vol. 16 No. 1, pp. 49-64.

Dyer, W.G. Jr and Whetten, D.A. (2006), "Family firms and social responsibility: preliminary evidence from the S\&P 500", Entrepreneurship: Theory and Practice, Vol. 30 No. 6, pp. 785-802.

Epstein, E.M. (1987), "The corporate social policy process: beyond business ethics, corporate social responsibility, and corporate social responsiveness", California Management Review, Vol. 29 No. 3, pp. 99-114.

Eriksson, P. and Kovalainen, A. (2015), Qualitative Methods in Business Research: A Practical Guide to Social Research, Sage, London.

European Commission (2003), "Commission recommendation of 6 May 2003 concerning the definition of micro, small and medium-sized enterprises", available at: https:/op.europa.eu/en/publicationdetail/-/publication/6ca8d655-126b-4a42-ada4-e9058fa45155/language-en (accessed 6 October 2019).

Fernando, M. and Almeida, S. (2012), "The organizational virtuousness of strategic corporate social responsibility: a case study of the Sri Lankan family-owned enterprise MAS Holdings", European Management Journal, Vol. 30 No. 6, pp. 564-576.

Fletcher, D. (2000), "Family and enterprise", in Carter, S. and Jones-Evans, D. (Eds), Enterprise and Small Business. Principles, Practice and Policy, Pearson, Harlow, pp. 155-165. 
JFBM 11,2
Gedajlovic, E., Carney, M., Chrisman, J.J. and Kellermanns, F.W. (2012), "The adolescence of family firm research: taking stock and planning for the future”, Journal of Management, Vol. 38 No. 4, pp. 1010-1037.

Glavič, P. and Lukman, R. (2007), "Review of sustainability terms and their definitions", Journal of Cleaner Production, Vol. 15 No. 18, pp. 1875-1885.

Gómez-Mejía, L.R., Cruz, C., Berrone, P. and De Castro, J. (2011), "The bind that ties: socioemotional wealth preservation in family firms", The Academy of Management Annals, Vol. 5 No. 1, pp. 653-707.

Gómez-Mejía, L.R., Haynes, K.T., Núñez-Nickel, M., Jacobson, K.J. and Moyano-Fuentes, J. (2007), "Socioemotional wealth and business risks in family-controlled firms: evidence from Spanish olive oil mills", Administrative Science Quarterly, Vol. 52 No. 1, pp. 106-137.

Hiebl, M.R.W. (2014), "A finance professional who understands the family: family firms' specific requirements for non-family chief financial officers", Review of Managerial Science, Vol. 8 No. 4, pp. 465-494.

Huang, Y.C., Wong, Y.J. and Yang, M.L. (2014), "Proactive environmental management and performance by a controlling family", Management Research Review, Vol. 37 No. 3, pp. 210-240.

IFERA (2003), "Family businesses dominate: families are the key players around the world, but prefer the backstage positions", Family Business Review, Vol. 16 No. 4, pp. 235-239.

Jones, M. (2009), "Disrobing the emperor: mainstream CSR research and corporate hegemony", Management of Environmental Quality, Vol. 20 No. 3, pp. 335-346.

Kammerlander, N. and Ganter, M. (2015), "An attention-based view of family firm adaptation to discontinuous technological change: exploring the role of family CEOs' noneconomic goals", Journal of Product Innovation Management, Vol. 32 No. 3, pp. 361-383.

Kashmiri, S. and Mahajan, V. (2014a), "A rose by any other name: are family firms named after their founding families rewarded more for their new product introductions?", Journal of Business Ethics, Vol. 124 No. 1, pp. 81-99.

Kashmiri, S. and Mahajan, V. (2014b), "Beating the recession blues: exploring the link between family ownership, strategic marketing behavior and firm performance during recessions", International Journal of Research in Marketing, Vol. 31 No. 1, pp. 78-93.

Kuttner, M. and Feldbauer-Durstmüller, B., (2018), "Corporate social responsibility in family firmsstatus Quo and future directions", International Journal of Business Strategy, Vol. 18 No. 1, pp. $47-68$.

Laguir, I., Laguir, L. and Elbaz, J. (2016), “Are family small- and medium-sized enterprises more socially responsible than nonfamily small- and medium-sized enterprises?”, Corporate Social Responsibility and Environmental Management, Vol. 23 No. 6, pp. 386-398.

Labelle, R., Hafsi, T., Francoeur, C. and Amar, W.B. (2018), "Family firms' corporate social performance: a calculated quest for socioemotional wealth", Journal of Business Ethics, Vol. 148 No. 3, pp. 511-525.

Le Breton-Miller, I. and Miller, D. (2006), "Why do some family businesses out-compete? Governance, long-term orientations, and sustainable capability", Entrepreneurship: Theory and Practice, Vol. 30 No. 6, pp. 731-746.

Le Breton-Miller, I. and Miller, D. (2009), "Agency vs. stewardship in public family firms: a social embeddedness reconciliation", Entrepreneurship: Theory and Practice, Vol. 33 No. 6, pp. 1169-1191.

Le Breton-Miller, I. and Miller, D. (2016), "Family firms and practices of sustainability: a contingency view", Journal of Family Business Strategy, Vol. 7 No. 1, pp. 26-33.

Levenburg, N.M. (2006), "Benchmarking customer service on the internet: best practices from family businesses", Benchmarking: An International Journal, Vol. 13 No. 3, pp. 355-373. 
Mark-Ungericht, B. and Weiskopf, R. (2007), "Filling the empty shell. The public debate on CSR in Austria as a paradigmatic example of a political discourse", Journal of Business Ethics, Vol. 70 No. 3, pp. 285-297.

Marquès, P., Presas, P. and Simon, A. (2014), "The heterogeneity of family firms in CSR engagement: the role of values", Family Business Review, Vol. 27 No. 3, pp. 206-227.

McGuire, J., Dow, S. and Ibrahim, B. (2012), "All in the family? Social performance and corporate governance in the family firm", Journal of Business Research, Vol. 65 No. 11, pp. 1643-1650.

Miller, D. and Le Breton-Miller, I. (2005a), "Management insights from great and struggling family businesses”, Long Range Planning, Vol. 38 No. 6, pp. 517-530.

Miller, D. and Le Breton-Miller, I. (2005b), Managing for the Long Run: Lessons in Competitive advantage from Great Family Businesses, Harvard Business Press, Boston, Massachusetts.

Miller, D. and Le Breton-Miller, I. (2006), "Family governance and firm performance: agency, stewardship, and capabilities", Family Business Review, Vol. 19 No. 1, pp. 73-87.

Miller, D., Le Breton-Miller, I. and Scholnick, B. (2008), "Stewardship vs. stagnation: an empirical comparison of small family and non-family businesses", Journal of Management Studies, Vol. 45 No. 1, pp. 51-78.

Miller, D., Lee, J., Chang, S. and Le Breton-Miller, I. (2009), "Filling the institutional void: the social behavior and performance of family vs non-family technology firms in emerging markets", Journal of International Business Studies, Vol. 40 No. 5, pp. 802-817.

Morelli, J. (2011), "Environmental sustainability: a definition for environmental professionals", Journal of Environmental Sustainability, Vol. 1 No. 1, pp. 19-27.

Morsing, M. and Perrini, F. (2009), “CSR in SMEs: do SMEs matter for the CSR agenda?", Business Ethics: A European Review, Vol. 18 No. 1, pp. 1-6.

Muttakin, M.B., Khan, A. and Subramaniam, N. (2015), "Firm characteristics, board diversity and corporate social responsibility: evidence from Bangladesh", Pacific Accounting Review, Vol. 27 No. 3, pp. 353-372.

Orth, U.R. and Green, M.T. (2009), "Consumer loyalty to family versus non-family business: the roles of store image, trust and satisfaction", Journal of Retailing and Consumer Services, Vol. 16 No. 4, pp. 248-259.

Panwar, R., Paul, K., Nybakk, E., Hansen, E. and Thompson, D. (2014), "The legitimacy of CSR actions of publicly traded companies versus family-owned companies", Journal of Business Ethics, Vol. 125 No. 3, pp. 481-496.

Porter, M.E. and Kramer, M.R. (2006), "The link between competitive advantage and corporate social responsibility", Harvard Business Review, Vol. 84 No. 12, pp. 78-92.

Preslmayer, C., Kuttner, M. and Feldbauer-Durstmüller, B. (2018), "Uncovering the research field of corporate social responsibility in family firms: a citation analysis", Journal of Family Business Management, Vol. 8 No. 2, pp. 169-195.

Rahman, S.. (2011), "Evaluation of definitions: ten dimensions of corporate social responsibility", World Review of Business Research, Vol. 1 No. 1, pp. 166-176.

Sageder, M., Mitter, C. and Feldbauer-Durstmüller, B. (2018), "Image and reputation of family firms: a systematic literature review of the state of research", Review of Managerial Science, Vol. 12 No. 1, pp. 335-377.

Schäfer, H. and Goldschmidt, R. (2010), "Corporate social responsibility of large family-owned companies in Germany", International Journal of Entrepreneurship and Small Business, Vol. 11 No. 3, pp. 285-307.

Sharma, P., Chrisman, J.J. and Gersick, K.E. (2012), "25 years of family business review: reflections on the past and perspectives for the future", Family Business Review, Vol. 25 No. 1, pp. 5-15.

\section{CSR in \\ Austrian family firms}


JFBM 11,2

Sharma, P. and Sharma, S. (2011), "Drivers of proactive environmental strategy in family firms", Business Ethics Quarterly, Vol. 21 No. 2, pp. 309-334.

Sirmon, D.G. and Hitt, M.A. (2003), "Managing resources: linking unique resources, management, and wealth creation in family firms", Entrepreneurship: Theory and Practice, Vol. 27 No. 4, pp. 339-358.

Soundararajan, V., Jamali, D. and Spence, L.J. (2017), "Small business social responsibility: a critical multilevel review", Synthesis and Research Agenda, International Journal of Management Reviews, Vol. 20 No. 4, pp. 934-956.

Steiger, T., Duller, C. and Hiebl, M.R.W. (2015), "No consensus in sight: an analysis of ten years of family business definitions in empirical research studies", Journal of Enterprising Culture, Vol. 23 No. 1, pp. 25-62.

Strigl, A. (2005), "Concerted action towards sustainable development", in Habisch, A., Jonker, J., Wegner, M. and Schmidpeter, R. (Eds), Corporate Social Responsibility across Europe, Springer, Berlin, pp. 125-139.

Sundarasen, S.D.D., Je-Yen, T. and Rajangam, N. (2016), "Board composition and corporate social responsibility in an emerging market", Corporate Governance, The International Journal of Business in Society, Vol. 16 No. 1, pp. 35-53.

Tagiuri, R. and Davis, J. (1996), "Bivalent attributes of the family firm", Family Business Review, Vol. 9 No. 2, pp. 199-208.

Thomas, D.R. (2006), "A general inductive approach for analyzing qualitative evaluation data", American Journal of Evaluation, Vol. 27 No. 2, pp. 237-246.

Uhlaner, L.M. (2006), "Business family as a team: underlying force for sustained competitive advantage", in Poutziouris, P.Z., Smyrnios, K. and Klein, S.B. (Eds), Handbook of Research on Family Business, Edward Elgar, Cheltenham, pp. 125-144.

Uhlaner, L.M., Berent-Braun, M.M., Jeurissen, R.J. and De Wit, G. (2012), "Beyond size: predicting engagement in environmental management practices of Dutch SMEs", Journal of Business Ethics, Vol. 109 No. 4, pp. 411-429.

Van Gils, A., Dibrell, C., Neubaum, D.O. and Craig, J.B. (2014), "Social issues in the family enterprise", Family Business Review, Vol. 27 No. 3, pp. 193-205.

Wagner, M. (2010), "Corporate social performance and innovation with high social benefits: a quantitative analysis", Journal of Business Ethics, Vol. 94 No. 4, pp. 581-594.

Wartick, S.L. and Cochran, P.L. (1985), "The evolution of the corporate social performance model", Academy of Management Review, Vol. 10 No. 4, pp. 758-769.

Wood, D.J. (1991), “Corporate social performance revisited”, Academy of Management Review, Vol. 16 No. 4, pp. 691-718.

Wiklund, J. (2006), "Commentary: 'family firms and social responsibility: preliminary evidence from the S\&P 500", Entrepreneurship: Theory and Practice, Vol. 30 No. 6, pp. 803-808.

Wirtschaftskammer Österreich (WKO) (2018), "WKO-analyse: familienunternehmen in Österreich", available at: https://news.wko.at/news/oesterreich/wko-analyse-familienunternehmen-oesterreich. html, (accessed 10 October 2019).

Yin, R.K. (2013), Case Study Research: Design and Methods, Sage, London.

Yu, A., Ding, H.B. and Chung, H.M. (2015), "Corporate social responsibility performance in family and non-family firms: the perspective of socio-emotional wealth", Asian Business and Management, Vol. 14 No. 5, pp. 383-412.

Zellweger, T.M., Kellermanns, F.W., Chrisman, J.J. and Chua, J.H. (2012), "Family control and family firm valuation by family CEOs: the importance of intentions for transgenerational control", Organization Science, Vol. 23 No. 3, pp. 851-868. 
Zellweger, T.M., Nason, R.S., Nordqvist, M. and Brush, C.G. (2013), "Why do family firms strive for nonfinancial goals? An organizational identity perspective", Entrepreneurship: Theory and Practice, Vol. 37 No. 2, pp. 229-248.

Zientara, P. (2017), "Socioemotional wealth and corporate social responsibility: a critical analysis", Journal of Business Ethics, Vol. 144 No. 1, pp. 185-199.

\section{Corresponding author}

Michael Kuttner can be contacted at: michael.kuttner@jku.at

CSR in

Austrian

family firms

For instructions on how to order reprints of this article, please visit our website:

www.emeraldgrouppublishing.com/licensing/reprints.htm

Or contact us for further details: permissions@emeraldinsight.com 